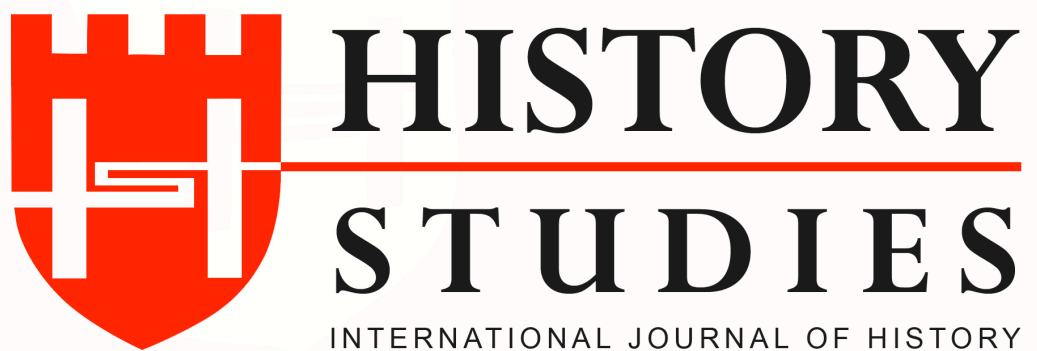

\author{
ISSN: 13094173 (Online) 1309 - 4688 (Print) \\ Volume 11 Issue 5, October 2019 \\ DOI Number: 10.9737/hist.2019.776 \\ Araştırma Makalesi
}

Makalenin Geliş Tarihi: 31.08.2019 Kabul Tarihi: 03.10.2019

Atıf Künyesi: Fatih Demirel-Songül Yılmaz Derin, “Osmanlı Ortaöğretim Kurumlarında Soruşturma Süreci (Örnek Bir Vaka Analizi)", History Studies, 11/5, Ekim 2019, s. 1525-1538.

\title{
Osmanlı Ortaöğretim Kurumlarında Soruşturma Süreci (Örnek Bir Vaka Analizi)
}

\section{The Process of Investigation in Institutions of Secondary Education in Ottoman Empire (A Case Study)}

\author{
Doç. Dr. Fatih Demirel-Songül Yılmaz Derin \\ ORCID No: 0000-0002-2098-4786 / 0000-0002-2721-1989 \\ Bursa Uludağ Üniversitesi
}

\begin{abstract}
Öz:
Bu çalışmada, Sultan II. Abdülhamid Dönemi'nde açılmış olan Kütahya İdâdîsi öğretmenlerinin Okul Müdürü hakkındaki şikâyetleri üzerine başlatılmış bir soruşturma vakası incelenmiştir. Vaka iki hususta önemli veriler içermektedir. Bunlardan ilki, bir idâdî müdürü hakkında başlatılmış olan soruşturmanın nasıl yürütüldüğüdür. Diğeri, Sultan II. Abdülhamid Dönemi'nde ülke geneline yaygınlaştırılan idâdî mekteplerinde yaşanan problemlerdir. Çalışmada öncelikle, vaka detaylarıyla aktarılmıştır. Sonuç ve değerlendirme bölümünde ise bir okul müdürü hakkında başlatılmış soruşturma sürecinin nasıl işlediği ve sonuçlandırıldığı, ülke geneline yaygınlaştırılmaya başlanmış idâdîlerde ne gibi problemlerin olduğu ele alınmıștır.
\end{abstract}

Anahtar kelimeler: Osmanlı, eğitim, disiplin, soruşturma

\begin{abstract}
In this study, a case of investigation that was started because of teachers' complaints about school principal in High School (İdâdî) of Kütahya constituted by Sultan Abdülhamid II is analyzed. The case contains two particular data. The first of them is how an investigation about a school principal conducted. The other one is problems of high schools (idâdî) which was generalized throughout the country at the period of Sultan Abdülhamid II. In this study, primarily, details of the case referred. In result and discussion part contains how an investigation about a school principal processed and concluded, and which problems occurred in high schools generalized throughout the country.
\end{abstract}

Keywords: Ottoman, education, discipline, investigation

\section{Giriş}

İdâdîler bir ortaöğretim kurumu olarak 1869 tarihli Maârif-i Umûmiye Nizâmnâmesi ile Osmanlı eğitim sistemi içerisindeki yerini almıştır. Ancak ilk iki örneğinin Tanzimat Dönemi'nde açılabildiği bu okullar, Sultan II. Abdülhamid Dönemi'nde ülke geneline yaygınlaştırılmışlardır. İdâdîler Nizâmnâme ile planlandığı gibi kalmamış farklı bir yapıda 
yaygınlaşmıştır ${ }^{1}$. Bu çerçevede vilayet merkezlerinde 7 yıl süreli ve genelde yatılı idâdîler açılmış, liva merkezlerinde ise 5 yıl süreli gündüzlü idâdîler açılmışır²

İdâdîlerin yaygınlaşmaya başlamasıyla okullarda, bina, öğrenci, öğretmen, idareci vb. kaynaklı çeşitli problemler çıkmıştır. İdâdî mektepleri arasında uygulama birliğini sağlayabilmek ve ortaya çıkabilecek disiplinle alakalı durumları çözebilmek amacıyla 1892 yılında idâdî mekteplerinin dâhili idareleri için bir Talîmâtnâme çıkarılmıştır. Elbette Talîmâtnâme öngörülen problemlere göre yazılmıştır. Eğitim kurumlarının Talîmâtnâmelerde planlandığı şekliyle idare edildiğini peşinen kabul etmek yanıltıcı olacaktır. Osmanlı modern eğitim kurumlarında meydana gelmiş disiplin vakalarının incelenmesi o kurumların nasıl idare edildiğine, karşılaşılan problemlerin neler olduğuna, o problemleri çözüm yollarına dair esas verileri sağlayacaktır. Osmanlı modern eğitim kurumlarındaki disiplin üzerine yapılmış çalışmalar mevcuttur. Bu çalışmaların bir kısmı eserlerin bir bölümünü oluşturmuş; bir kısmı ise doğrudan konuyu değerlendirmiştir ${ }^{3}$. Osmanlı modern eğitim kurumlarında karşılaşılan bir disiplin vakasında soruşturma sürecinin nasıl işletildiğine dair doğrudan bir çalışma mevcut değildir. $\mathrm{Bu}$ çalışma ile Osmanlı modern eğitim kurumlarında bir okul müdürü hakkında başlatılmış soruşturmanın nasıl yürütüldüğü ortaya konulmaya çalışılmıştır.

Kütahya İdâdîsi, 1890'ların başında, okul binasının tamamlanmasıyla eğitim-öğretim faaliyetlerine başlamıştır. Beş yıllık gündüzlü idâdî statüsünde olan okulun açılmasıyla Kütahya Rüşdiyesi de okul bünyesine alınmıştır ${ }^{4}$. Eğitime başladığ 1 ilk yıllarda Kütahya İdâdîsinde çeşitli problemler yaşanmıştır.

\section{Kütahya İdâdîsi Muallimlerinin Şikâyetleri}

Kütahya İdâdîsi muallimlerinden resim dersi Muallimi Mehmed Necati, coğrafya ve tarih dersleri Muallimi Arif, Fransızca dersi Muallimi Serab, ulûm-1 dîniyye dersi Muallimi Mustafa Şükrü ve Türkçe dersi Muallimi Yahya tarafından, 18 Ağustos 1893'te bir şikâyet dilekçesi kaleme alınmış ve Maârif Nezâretine gönderilmiştir. Dilekçede 1890 yılında açılan Kütahya İdâdîsinde daha önce müdürlük yapmış olan Enver Bey ve Yunus Efendi'nin ismi zikredilmektedir. Enver Bey hariç tutulmak üzere Yunus Efendi ve hâlihazırdaki Okul Müdürü Abdurrezzak Efendi zamanında okulun kötü yönetildiği ifade edilmektedir. Suçlamalar ise o dönemin Okul Müdü Abdurrezzak Efendi’yle ilgilidir. Eleştiri ve suçlamalar yedi madde halinde kaleme alınmıştır. Buna göre:

1. Kütahya İdâdîsi Müdürü Abdurrezzak Efendi'nin 15 y1l Kütahya Rüşdiye Mektebinde muallimlik yapması eşraf ve devlet görevlileri ile şahsi ilişkilerini geliştirmesine sebep olmuştur. Bundan dolayı yukarıda zikredilenlerle iyi ilişkilerini devam ettirmeyi kendisine

\footnotetext{
${ }^{1}$ İdâdî mektepleri hakkında ayrıntılı bilgi için bkz. Fatih Demirel, Mekteb-i İdâdî, Atatürk Üniversitesi, Sosyal Bilimler Enstitüsü, Yayınlanmamış Doktora Tezi, Erzurum, 2010.

${ }^{2}$ Osmanlı modern eğitim kurumlarının hiyerarşik yapısı hakkında bkz. Fatih Demirel, "Osmanlı Eğitim Siteminin Modernleşmesi Sürecinde Hiyerarşi”, Uludă̆ Üniversitesi Eğitim Fakültesi Dergisi, 25/2, 2012.

${ }^{3}$ Osmanlı modern eğitim kurumlarında disiplin konusu için bkz. Mustafa Gündüz, "Son Dönem Osmanlı Eğitiminde Disiplin ve Cezalandırma (1847-1920), Doğu Batı, 13/53, 2010; Selçuk Akşin Somel, Osmanlı'da Eğitimin Modernleşmesi (1839-1908) (İslamlaşma, Otokrasi ve Disiplin), Ceviren: Osman Yener, İstanbul, 2010; Benjamin C. Fortna, Mekteb-i Hümayûn (Osmanlı İmparatorluğu'nun Son Döneminde İslâm, Devlet ve Ĕ̌itim), Çeviren: Pelin Siral, İstanbul, 2005; Arzu M. Nurdoğan, Modernleşme Döneminde Osmanll'da İlköğretim, İstanbul, 2016; Fatma Kaya Doğanay, Tanzimat'tan Cumhuriyet'e Rüşdiye Mektepleri, Atatürk Üniversitesi, Sosyal Bilimler Enstitüsü, Yayınlanmamış Doktora Tezi, Erzurum 2011.

${ }^{4}$ Kütahya İdâdîsi ile ilgili bkz. Ekrem Kaçmaz, Kütahya Lisesi ve Tarihi Gelişimi, Selçuk Üniversitesi, Eğitim Bilimleri Enstitüsü, Yayınlanmamış Yüksek Lisans Tezi, Konya, 2010; Serap Kölemen (Yüce), 19. Yüzyılın Sonu ve 20. Yüzyılın Başlarında Kütahya Sancă̆ı'nda Eğitim, Afyonkarahisar Kocatepe Üniversitesi, Sosyal Bilimler Enstitüsü, Yayınlanmamış Yüksek Lisans Tezi, 2007.
} 
meslek edinmiştir. Bu da şahsi menfaatine uygun düşmeyen vatan evlatlarının feda edilmesine sebep olmuştur.

2. Okul Müdürü, öğrencilere eşit olarak davranmamaktadır. İlk maddede ifade edilen ilişkiler nedeni ile müdürlük vasfina yakışmayacak şekilde, bazı öğrencilere "beyim, efendim" gibi taltif edici surette hitap ederken diğer bir kısmına bunun zittı olarak, burada ifade edilemeyecek şekilde, kaba ifadeler kullanmaktadır. $\mathrm{Bu}$ yaklaşım, öğrencilerin okul aidiyetlerinin oluşmasını engellemektedir.

3. Öğrenciler, yoklama zamanlarında okulda bulunmama, istedikleri zaman okuldan çıkma, okula gelmeme gibi talîmâta aykırı davranışlar sergilemektedirler. Bu durumun düzeltilmesi için Müdüre rica edilmesine rağmen $\mathrm{o}$, bu problemlerle ilgilenmemiştir. Öğrencilerin okula silah getirmesi sebebiyle diğer öğrencileri darp etmesi, yaralaması gibi vakalar yaşanmaktadır. $\mathrm{Bu}$ durum, okulun, öğrencileri terbiye etmek yerine aksi yönde yetiştiren bir kuruma dönüşmesine sebep olmakta ve okulu sıradan bir mahalle mektebi derecesine indirmektedir. Yukarıda ifade edilen disiplin eksikliği, eğitimin değerini tam olarak kavrayamamış ebeveynlerin, çocuklarını okula göndermeme yönünde karar almalarına sebebiyet vermektedir.

4. Okulda, uygun olmayan davranışlar sergileyen öğrenciler, ders vakitlerinde öğretmenler, ders vakitleri dışında ise mubassır ve hademeler tarafından uyarıldıklarında, bu uyarıları dikkate almadıkları gibi uyarılar karşısında laubali davranmaktadırlar. İfade edilen durum sebebiyle Müdür nezdinde şikâyette bulunulmasına rağmen o, bu şikâyetlere kayıtsız kalınmaktadır.

5. Arapça ve Farsça dersleri Müdür'ün uhdesindedir. Bu derslerde öğrenciler dershane içerisinde gülüp oynamaktadırlar. Müdür derslere yarım saat geç girmektedir. Eğer okula bir ziyaretçi gelmişse derse hiç gitmemektedir. Müdür, derse girdiğinde sandalye üzerinde uyumaktadır.

6. Eğitim-öğretim dönemi başlangıcında, kayıt zamanından sonra, okula öğrenci kabulü Talîmâtnâme'ye aykırı olmasına rağmen, Abdurrezzak Efendi bazı şahısları öğrenci olarak kabul etmiştir. Onlardan bir kısmının yaşları dahi kabule uygun değildir. Umumi imtihandan iki, üç ay önce, sanki misafir ve ihtiyat sınıfları varmışçasına okula öğrenci kaydı yapmaktadır. Umumi imtihanlarda, hatta ders yoklama defterlerinde isimleri olmayan, umumi imtihana girmemiş öğrencilere, öğretmen ve mümeyyizlerin haberi olmaksızın kendi kararıyla, sınav yapmadan notlar vermektedir. Hatta onları çok başarılı gösterip tevzi-i mükâfatta onlara ödüller vererek taltif etmektedir. İfade edilen sahtekârlıkların affı mümkün değildir.

7. Tevzi-i mükâfatta sınıf birincilerine verilen saat ve kitap ödüllerinde usulsüzlük yapılmış, ödüllerin dağıtımında başarı kıstasına dikkat edilmemiş̧ir. Diğer taraftan tevzi-i mükâfat için ayrılan ödenek usulsüz kullanılmıştır. Yaklaşık 500 kuruş tutacak harcamalar yaklaşık 700 kuruş olarak gösterilmiş ve zimmete para geçirilmiştir.

Yukarıda ifade edilen eleştiri ve suçlamalardan sonra gereğinin yapılması arz edilmektedir5.

\section{Kütahya İdâdîsi Müdürü Abdurrezzak Efendi’nin Muallimler Hakkındaki Şikâyetleri}

Muallimlerin şikâyetlerine mukabil Okul Müdürü Abdurrezzak Efendi de muallimlerden Serab ve Yahya Efendiler hakkında, Hüdavendigâr Maârif Müdürlüğüne, farklı tarihlerde iki şikâyet arz etmiştir.

Bunlardan ilki Fransızca Muallimi Serab Efendi hakkındadır. Şikâyetin temelinde Muallimin okul dışında özel ders vermesi suçlaması yatmaktadır. Müdürlügün yazısında, Serab

${ }^{5}$ BOA, MF.MKT., 251/27. (Kütahya Mekteb-i İdâdîsi muallimlerinin Maârif Nezâretine gönderdikleri 18 Ağustos 1893/6 Ağustos 1309 tarihli dilekçe) 
Efendi’nin özel ders verme meşguliyeti nedeniyle okuldaki derslerini düzenli takip etmediği, derslere ehemmiyet vermediği ifade edilmektedir. Bu nedenle idâdîlerin dâhili idarelerini düzenleyen Talîmâtın 3. maddesine istinaden Serab Efendi'nin Okul Müdürü tarafindan uyarıldığı, ancak bir sonuç alınamadığı belirtilmektedir. Okul Müdürü uyarılar sırasında kendisinin Serab Efendi tarafından tehdit edildiğini belirtmektedir. Diğer taraftan kardeşini Bursa İdâdîsinin yatılı kısmına kaydettirmek isteyen Serab Efendi'nin, bunda başarılı olamaması da yukarıda ifade edilen problemlere bir kaynak olarak gösterilmiştir. Sonuç olarak, yazıda Serab Efendi'nin durumunun diğer öğretmenler için bir örnek teşkil edeceği belirtilmek suretiyle okulda kalmasının uygun olmayacağı ifade edilmiş ve gereği arz edilmiştir ${ }^{6}$.

Abdurrezzak Efendi'nin, hakkında şikâyet arz ettiği diğer muallim Yahya Efendi'dir. Şikâyetin temelini okulun Türkçe Muallimi Yahya Efendi'nin eylül ayında sekiz dersine mazeretine binaen, on dersine ise mazeretsiz olarak girmemiş olması oluşturmaktadır. Okul idaresi Yahya Efendi'nin girmediği dersler için, Talîmâtın 59. maddesine istinaden maaş kesim cezası uygulamıştır. Ancak Yahya Efendi okulun diğer personelini de içeren maaş pusulasını imzalamamıştır. Bu nedenle de maaş ödeme hazırlıkları aksamıştır. Okul idaresi, yukarıda ifade edilen hususlar doğrultusunda, Hüdavendigâr Maârif Müdürlüğünden, maaş senedi üzerinde bir muallimin imzasının bulunmayışının maaşların ödenmesi için bir engel teşkil edip etmeyeceğini sormakta ve acil olarak telgrafla cevap istemektedir. Diğer taraftan, Abdurrezzak Efendi, mazeretsiz olarak üç defa dersine girmeyen muallimin, Talîmâtın 6. Maddesine istinaden müstafi sayılması gerektiğini ve derse girmeme durumunun diğer muallimlere örnek teşkil etmemesi için gereğinin hemen yapılması gerekliliğini ifade etmiştir. Ancak şahsı hakkında şikâyette bulunan muallimler arasında Yahya Efendi'nin de bulunması nedeniyle, gereğinin kendisi tarafından yapılmasının hakkındaki şikâyete karşı bir mukabele olarak değerlendirilebileceğini belirtmiş ve gereğini arz etmiştir. Yazıyla beraber, okulun mubassırı Mehmed Nuri Efendi tarafından tutulan, Yahya Efendi ile ilgili, yevmiye defterinin bir örneği de gönderilmiştir ${ }^{7}$. Yevmiye pusulasında, Yahya Efendi'nin eylül ayı boyunca mazeretine binaen veya mazeretsiz olarak girmediği dersler gün gün yazılmıştır.

\section{Sorușturma Komisyonunun Olușturulması}

Muallimler tarafindan gönderilmiş olan şikâyet dilekçesi Maârif Nezâreti tarafindan kabul edilmiş ve vakanın soruşturulması için Hüdavendigâr (Bursa) Maârif Müdürü, Maârif Nâzırı Zühtü Paşa tarafından görevlendirilmiştir (30 Eylül 1893/18 Eylül 1309) ${ }^{8}$. İfade edilen görevlendirme sonrasında, Türkçe dersi Muallimi Yahya tarafından Maârif Nezâretine yeniden bir dilekçe yazılmış ve şikâyetlerin, Kütahya'da bulunan, Hüdavendigâr vilayeti Vali Muavini Celal Bey veya askeriyeden ve mülkiyeden oluşturulacak bir komisyon tarafindan soruşturulması arz edilmiştir (8 Ekim 1893/26 Eylül 1309). Buna mukabil, Kütahya İdâdîsi Müdürü Abdurrezzak Efendi de Nezârete bir yazı göndermiş ve Fransızca Muallimi Serab Efendi'nin kışkırtması sonucu yapılmış olan şikâyetle ilgili soruşturmanın resmi makamlara havale edilmesi durumunda hakikatlerin ortaya çıkacağını bildirmiştir (9 Ekim 1893/27 Eylül $1309)^{9}$.

\footnotetext{
${ }^{6}$ Aynı dosyada, (Kütahya İdâdî Mektebi Müdürü Abdurrezzak tarafindan Hüdavendigâr Maârif Müdürlüğüne gönderilen 5 Ekim 1893/23 Eylül 1309 tarihli yazı.)

7 Aynı dosyada, (Kütahya İdâdî Mektebi Müdürü Abdurrezzak tarafindan Hüdavendigâr Maârif Müdürlüğüne gönderilen 15 Ekim 1893/3 Teşrîn-i evvel 1309 tarihli yazı.)

8 Aynı dosyada, (Maârif Nezâretinden Hüdavendigâr Vilayeti Maârif Müdürlüğüne gönderilen 30 Eylül 1893/18 Eylül 1309 tarihli şukka)

9 Aynı dosyada, (Kütahya İdâdîsi Müdürü Abdurrezzak Efendi’nin Maârif Nezâretine gönderdiği 9 Ekim 1893/27 Eylül 1309 tarihli yazı)
} 
Yukarıdaki gelişmelerden sonra, Hüdavendigâr Valisi tarafından Kütahya Mutasarrıflığına gönderilen şukka ile askeriyeden ve mülkiyeden seçilecek bir komisyonun oluşturularak gerekli soruşturmanın yapılması ve neticenin Valiliğe bildirilmesi istenmiştir ${ }^{10}$. Kütahya İdare Meclisinin, 12 Mart 1894/28 Şubat 1309 tarihli toplantısında Meclis azaları Mehmed ve Artaki ile Meclis kâtibi Rıfat Efendiler komisyon üyesi olarak seçilmiştir. Karar bir gün sonra Kütahya Redif Kumandanlığına bildirilmiştir. Sonraki yazışmalardan anlaşıldığına göre ilgili komisyon başkanlığına Kütahya Redif Kumandanlığından Miralay (Albay) Ali Rıza Bey atanmıştır. Soruşturma komisyonu oluşturulduğu o ilk haliyle kalmamış ve sonraki tarihlerde komisyon üyelerinde değişikliğe gidilmiştir. Komisyon azalarından Mehmed ve Rıfat Efendilerin yerlerine Evkaf Müdürü Hakkı ve İdare Meclisi azalarından Şükrü Beyler atanmışlardır ${ }^{11}$. Komisyon üyelerindeki değişikliğin sebebi belirtilmemiştir. Komisyondaki değişimden kısa bir süre üyelerden Evkaf Müdürü Hakkı Bey ve İdare Meclisi azası Artaki Efendi aşar memuru olarak başka kazalara tayin edilmişlerdir. Ancak iki komisyon üyesinin yerlerine yenileri tayin edilmemiştir. Yeni görevlendirmenin yapılmama sebebi ise soruşturmanın devam etmekte olduğu ve yeni görevlendirme olursa onların sürece vakıf olamayacakları olarak ifade edilmiştir. İlgili yazışmadan anlaşılan diğer bir husus soruşturma tamamlanıncaya kadar Okul Müdürü Abdurrezzak Efendi'nin sancaktan başka bir yere seyahatine izin verilmeyecek olduğunun ifade edilmesidir ${ }^{12}$.

\section{Soruşturma Komisyonunun İncelemesi \\ 4.1. Muallimlerin ifadeleri}

Üyelerinde değişim olmakla birlikte soruşturma komisyonu Ali Rıza Bey’in başkanlığında iki defa toplanmıştır. İlk toplantıda muallimler dinlenmiş ve onların suçlamaları kaydedilmiştir. Sonrasında, muallimler tarafından dile getirilen suçlamalardan ilk ikisi Müdür Abdurrezzak Efendi'ye okunmuş ve kendisine savunma hakkı verilmiştir. Müdürün vermiş olduğu cevaplar da kayıt altına alınmıştır.

Muallimlerin ifade ettikleri hususlar ve Abdurrezzak Efendi'nin verdiği cevaplar aşağıda sırasıyla ele alınacaktır. İfade tutanaklarından muallimlerin tamamının hazır bulunduğu anlaşılmaktadır ${ }^{13}$. Komisyon tarafindan muallimlere yöneltilen sorular, onların daha önce vermiş oldukları şikâyet dilekçesi ile alakalıdır. Komisyon, muallimlere ilk olarak Müdür Abdurrezzak Efendi hakkındaki şikâyetlerinin neler olduğunu sormuş ve cevapların yazılı olarak kaydedileceğini ifade etmiştir. Muallimler öncelikle Abdurrezzak Efendi'nin idari zafiyetlerini dile getirmişlerdir. Onların ifadesiyle...

1- Okulda disiplin vahim durumdadır. Öğrencilerin birbirlerini bıçakla yaralaması, sokaklarda halka karşı saygısızlık yapılması gibi davranışlar normal görülmeye başlanmıştır. Örneğin, önceki y1l, öğrencilerden İbrahim Efendi okulun bahçesinde, teneffüs saatinde, Ohannes Efendi'yi baldırına bıçak saplamak suretiyle yaralamıştı.

\footnotetext{
${ }^{10}$ Aynı dosyada, (Hüdavendigâr Valiliğinden Kütahya Mutasarrıflığına gönderilen 19 Aralık 1893/7 Kanûn-1 evvel 1309 tarihli şukka)

${ }_{11}$ Aynı dosyada, (Kütahya Mutasarrıflığından Kütahya Redif Kumandanlığına gönderilen 13 Haziran 1894/1 Haziran 1310 tarihli yazı.)

${ }_{12}$ Aynı dosyada, (Kütahya Mutasarrıflı̆̆ından Kütahya Redif Kumandanlığına gönderilen 2 Ağustos 1894/21 Temmuz 1310 tarihli yazı.)

${ }^{13}$ Aynı dosyada, (Soruşturma Komisyonu tarafından kaleme alınan ifade tutanakları. Dosyadaki tutanaklar ifade sırasında yazıldığı haliyle bulunmaktadır. Tutanak üzerinde 15 Eylül 1311 tarihi yazılmıştır. Ancak diğer evrakta verilen bilgilerden tarihin 1310 yerine sehven 1311 şeklinde yazılmış olduğu değerlendirilmektedir. Zikredilen tarih komisyonun ikinci toplantısına aittir. İfadelerin alındığı ilk toplantının tarihi, belgelerde yazılmamış olmakla birlikte, Okul Müdürü'nün beyanından (Bundan dört mâh mukaddem bazı esbâba mebnî şifahen taraf-ı âcizânemden verilen cevabı kabul edemeyeceğim gibi bu defa dahi...), ilk ifadelerin Mayıs ayı içerisinde (1894) alınmış olduğu anlaşılamamaktadır.)
}

\section{History Studies}


İbrahim Efendi hiçbir ceza almadığı gibi Müdür'ün imzasıyla diploma ve hüsn-i hal (iyi hal) alarak Bursa İdâdîsine kayıt yaptırmıştır. Birkaç ay önce, Okul Müdürü'nün vermekte olduğu Arapça dersinde 1. sınıf öğrencilerinden Sadık Efendi, Lütfü Efendi ismindeki diğer bir öğrenciyi bıçakla yaralamıştır. Sadık Efendi, okuldan atılması gerektiği halde, halen okula devam etmektedir. Yine 3. sınıf öğrencisi Markar Efendi, sınıf arkadaşları, Osman, Mustafa ve Arif Efendiler ile birlikte sokakta insanları rahatsız etmişler ve gece vakti bir evin kapısını taşlamışlardır. Bu durum Markar Efendi'nin kardeşi tarafından okula şikâyet olarak tekrar tekrar bildirilmiştir. Okul Müdürü gerekli cezalandırmayı yapmaktansa vakayı hafif bir tektir ve dayak ile geçiştirmiştir. Yukarıda ifade ettiklerimiz Okul Müdürü'nün idari zafiyetini göstermektedir. Gerekli soruşturmanın komisyonca yapılmasını arz ediyoruz.

2- Soruş̧urma komisyonunun ikinci sorusu Müdür'ün bazı öğrencilere tanımış olduğu ayrıcalıklarla ilgilidir. Muallimlerin ifadesine göre Müdür usulsüz olarak okula öğrenci kaydetmektedir. Muallimler, usulsüz kayıtlara, isim belirtmek suretiyle örnekler de vermişlerdir. Usulsüz kayıtlara örnek olarak 1. sınıftan Faruk Efendi, önceki yıl kaydı yapılan öğrencilerden Mehmed Efendi, 3. sınıf öğrencilerinden Agop Efendi'nin isimleri verilmiştir. Bunun yanında, kayıt defterine bakılması halinde daha başka usulsüz kayıtların yapıldığının da anlaşılabileceği ifade edilmiştir. Diğer taraftan mahalle mektebinden gelip, herhangi bir sınava tabi tutulmadan çeşitli sınıflara kaydedilen öğrencilerin varlığına işaret edilmiştir. Örnek olarak Pertev, Bekir ve Faruk isimli öğrenciler verilmiştir. $\mathrm{O}$ öğrenciler mahalle mektebinden sonra doğrudan 1 . sinıfa kaydedilmişlerdir. Muallimlerin ifadesine göre mahalle mektebini bitirip herhangi bir sınav yapılmadan doğrudan 3. sınıfa kaydedilen öğrenciler de vardır. $\mathrm{Bu}$ hususa örnek olarak Abdullah isimli öğrenci gösterilmiştir. Müdür'ün yapmış olduğu usulsüzlüklere bir örnek de sinavlarla ilgilidir. Muallimlerin ifadesine göre dönemin Kütahya Mutasarrıfının oğlu Nazmi Bey birkaç dersin sınavına girmemiş olduğu halde (sınav zamanında babasıyla birlikte şehir dışında olduğu ifade ediliyor.) ona Müdür tarafından sınavlara girmiş gibi notlar verilmiş ve verilen yüksek notlarla onun sınıf ikinciliğini elde etmesi sağlanmıştır. Bununla da yetinilmeyip sınıf birincisine mükâfat olarak verilen saat, ikinci gösterilen Nazmi Bey’e verilmiştir. Yine 3. sınıf sınavlarına girmedikleri halde bir üst sınıfa geçirilmiş öğrencilerin varlığına işaret edilmiş, Hasan ve Ahmed Efendiler örnek gösterilmişlerdir.

3- Komisyonun üçüncü sorusu yolsuzlukla ilgilidir. Muallimler konuyla ilgili çeşitli örnekler vermişlerdir ve iddiaları oldukça ciddidir. Öncelikle sınıf birincilerine ödül olarak verilen saatlerin değerinden fazla meblağa satın alınmış gösterildiği iddia edilmiştir. Örnek olarak da son sınıf öğrencisi Nuri Efendi'ye verilen saat komisyona takdim edilmiş ve o saatin 100 kuruş değerinde gösterildiği ifade edilmiştir. Masraf pusulasında, 15 kuruş harcanarak yazdırıldığ Efendi'ye 5 kuruş verildiği belirtilmiş ve konunun ilgiliye sorulabileceği ifade edilmiştir. Harcamalarla ilgili yapıldığı iddia edilen yolsuzluklara daha başka örnekler de verilmektedir. İddia edilen yolsuzluklar 1893 y1lında gerçekleştirilmiş olan mükâfat töreni harcamalarıyla alakalıdır. İlgili harcamalara ait tutulmuş kayıtlar soruşturma dosyası içerisinde mevcuttur.

4- Komisyonun öğretmenlere yönelttiği dördüncü soru, Müdür'ün görevleriyle ilgili usulsüzlüklerin neler olduğu yönündedir. Muallimler, konuyla ilgili örnekler verirken ilgili Talîmâtnâme'ye atıfta bulunmuşlar, uygulamaların hangi maddeye aykırılık teşkil ettiğini belirtmişlerdir. Hendese (geometri), hesap ve resim dersleri Muallimi Galib Bey'in öğrencilerden bazılarına tasallut etmesi sonucu Cevat, İhsan ve Arsin isimli 
öğrencilerin öğretmeni şikâyet etmelerine rağmen Müdür tarafından işlem yapılmadı̆̆ı ifade edilmektedir. Ancak olayın duyulmasından sonra Galib Bey istifa edip Okul Müdürü'nden iyi haline dair bir vesika almak suretiyle onu İdare Meclisine ibraz edip okuldan ayrılmıştır. Muallimler bu durumun Talîmâtnâme'nin 3. maddesine aykırı olduğunu beyan etmişlerdir. Talîmâtnâme'nin 4. maddesine aykırı olarak, okulda meydana gelen vukuatın Maârif Müdürlüğüne bildirilmediği kanaatinde olduklarını belirtmişlerdir. Okul Müdürü Talîmâtnâme'nin 5. maddesi gereğince bir kereye mahsus olmak üzere eğitim kadrosu ile toplantı yapmış; ancak toplantıda okulda meydana gelen usulsüzlükler dile getirildiğinde, Müdürden, memuriyetimin devamı için mevcut uygulamaların tabii olduğu cevabı alınmıştır. Yukarıda örnekleri verildiği gibi Talîmâtnâme'nin 24. maddesine göre öğrenci kaydı yapılması gerekirken buna riayet edilmemiştir. Yine öğrenci kaydıyla ilgili olarak Talîmâtnâme'nin 25. maddesinde belirtilen hükümlerin uygulanmadığı belirtilmekte; öğrencilerin aşı belgesi gibi belgelerinin olmayışı örnek gösterilmektedir. Talîmâtnâme'nin 37. maddesi gereğince muallimler tarafindan öğrenciler için yazılan aferin ve tahsin belgelerinin Müdür tarafından verilmediği, bunun da muallimi öğrenci karşısında mahcup ettiği gibi öğrencilerin terbiyelerine zarar verdiği ifade edilmektedir. Muallimler tarafından dile getirilen diğer bir konu, Müdür Abdurrezzak Efendi'nin, Türkçe Muallimi Yahya Efendi'nin hastalığ 1 sebebiyle giremediği dersler için, Talîmâtnâme'nin 59. maddesi gereğince, yerine bir vekil tayin etmek yerine derse girmiyor suçlamasıyla Maârif Müdürlüğüne şikâyet etmesidir. Okulda yaşanan problemlerden birisi de öğrencilerin, Talîmâtnâme'nin 64. maddesi aksine, silah, bıçak gibi okulda bulundurmaması gerekenleri taşımalarıdır. Muallimler, soruşturma komisyonunun öğrenciler üzerinde arama yapmaları halinde bunu görebileceklerini ifade etmişlerdir. Önceki gün Reis Efendi'nin oğlunun bıçak taşıdığının mubassırlar tarafından tespit edildiği ve Müdürün bu durumdan haberdar edildiği örnek olarak verilmiştir. Diğer bir idari zafiyet örneği olarak da öğrencilerin derslere devamlarının ve okula geliş gidiş saatlerinin takip edilmemesi gösterilmiştir. Bu iki hususun Talîmâtnâme'nin 68. ve 69. maddelerine aykırı olduğu vurgulanmıştır. Muallimler son olarak öğrencilerin terbiyelerinin kalmadığını, karşılarında sigara içtiklerini, tütün bulundurduklarını belirtmişler ve komisyon tarafindan yapılan denetimde iki öğrenciden çıkan bıçağın iddia edilenleri ispata yeteceğini ifade etmişlerdir.

\subsection{Okul Müdürü Abdurrezzak Efendi'nin İfadesi}

Komisyon, muallimleri dinledikten sonra, okul disiplini ve şahsı hakkındaki isnatları cevaplaması için Okul Müdürü Abdurrezzak Efendi'ye sorular yöneltmiştir. Komisyon, muallimler tarafindan dile getirilen her bir şikâyet konusunu, tutmuş oldukları zabittan, sırasıyla okumuşlar ve akabinde Abdurrezzak Efendi'nin savunmasını kayıt altına almışlardır. Abdurrezzak Efendi'nin muallimler tarafından isnat edilen ilk suçlamaya yönelik verdiği cevaptan iddiaların gerçek olduğu anlaşılmaktadır. Zira Okul Müdürü bir yıl önce, öğrencilerden İbrahim Efendi'nin kaza ile Ohannes Efendi'yi bıçakla yaralamış olduğunu beyan etmiştir. $\mathrm{Bu}$ vaka nedeniyle İbrahim Efendi'nin şiddetli bir dayakla cezalandırıldığı ve terbiye olduğu; ancak olayın Maârif Müdürlüğüne bildirilmediği, yaralanan öğrencinin babasının İbrahim Efendi'yi affettiği ve onun isteğiyle durumun okulun sicil defterine işlenmediği Abdurrezzak Efendi'nin ifadelerinden anlaşılmaktadır. Benzer bir hadise olarak öğrencilerden Lütfi Efendi'nin çakı ile yaralanmış olması sebebiyle Sadık Efendi’yi şikâyet etmiş olduğu, kendisi tarafından kontrol edildiğinde önemli bir yaralanma olmadığının tespit edilip Sadık Efendi'nin kendisi tarafindan terbiye edildiği! Abdurrezzak Efendi'nin ifadesinde yer almıştır. Yine üçüncü sınıf öğrencilerinden Sadık Efendi’ye terbiyesizlik etmiş öğrencilerin 
kendisi tarafından terbiye edilip dövüldüğ̈ ancak bu vakanın da sicile işlenmeyip Maârif Müdürüne bildirilmediği Abdurrezzak Efendi tarafından beyan edilmiştir. Okul Müdürü, kendisine yöneltilen ilk soruya, son olarak bu gibi durumların sicile işlenmesi gerektiğine yönelik bir talîmâtın olmadığı ve bu gibi ufak tefek şeylerin Maârif Müdürlüğüne yazılmasına gerek olmadığı cevabını eklemiştir.

Abdurrezzak Efendi'nin muallimler tarafından zikredilen ilk iddiaya verdiği cevapları tamamlamasından sonra, komisyon ikinci sıradaki suçlamaları okumuş ve Okul Müdürü’nden ifadesini talep etmiştir. Abdurrezzak Efendi'nin vermiş olduğu ifade şöyledir:

\begin{abstract}
“Okunan iddiaları dinledim. Okula, vakitsiz öğrenci alındı̆̆ olmuşsa da bu birkaç günden ibarettir. Çünkü halk henüz alışmamıştır. Kayıt zamanı ilan olunduktan sonra çocukların başvurularında gecikmeler olmuştur. Sınav yapılmaksızın üst sınıflara öğrenci kaydı olmamıştır. 3. sınıfa kaydedilmiş olan Abdullah Efendi medreseden gelmiştir. Arapçadan sınav yaptım; layık gördüm aldım. O çocuk yalnızca Farisî, hesap dersinden dört işlem biliyordu. Coğrafya ve müfredattaki diğer dersler hakkında bilgisi yoktu. Ancak şimdi akranları seviyesine ulaşmıştır. Pertev, Faruk ve Bekir Efendiler sınava girdiler. İkinci sınıfa layık gördüm ve oraya kaydettim. Onların yaşları da uygundur. Agop Efendi'yi 3. sınıfa aldım. Bir müddet devam etmedi. Sonra yine sinıfina devam etmeye başladı. Ögretmenlerin ricası üzerine kabul edildi. Mutasarrıfin oğlu Nazmi’ye mükâfat olarak saat verdim. Zaten her yıl iki saat alınıyormuş. Bu yıla mahsus 3 tane aldım. Sinıf birincisine kitap verdim, ikincisi olan Nazmi Bey'e saat verdim. Nazmi Bey'in sınava girmediği hakkındaki iddiayı kabul etmem. Glyaben not verdi ifadelerini dahi kabul etmem. Öğrencilerden Ahmed Efendi bir dersten sınava girmediği halde, arkadaşları gibi bir üst sınıf (3. sınıf) defterine kaydedilmişse de bunun hükmü yoktur."
\end{abstract}

Buraya kadar zikretmiş olduğumuz ifadeler komisyonun ilk toplantısında kaydedilen tutanaklardır. İlk toplantının neden sorular tamamlanmadan sonlandırıldığına dair bir bilgi bulunmamaktadır. Ancak ilk toplantıda öğretmenlerin ifadelerinin alınması, ifadeler doğrultusunda öğrencilerin aranması ve sonrasında Abdurrezzak Efendi’nin ifadesine başlanılıp ilk iki soruya alınan cevaplarla gün tamamlanmıştır.

Soruşturma komisyonu, aradan uzun bir süre ${ }^{14}$ geçtikten sonra, 27 Eylül 1894'te ikinci kez bir araya gelmiş ve muallimlerin üçüncü sıradaki şikâyetlerini okuyarak Abdurrezzak Efendi'den cevap istemiştir. Abdurrezzak Efendi, dört ay önce bazı sebeplerden dolayı sözlü olarak vermiş olduğu cevapları kabul edemeyeceğini ve şimdi de bu isnatlara şifahen cevap veremeyeceğini, daha sonra yazılı olarak cevap vereceğini belirtmiştir.

\title{
5. Soruşturmanın Karar Süreci
}

Soruşturma komisyonu başkanı Ali Rıza Bey, Kütahya Redif Kumandanlığına hitaben kaleme aldığı yazısında soruşturma ile ilgili düşüncelerini ve süreci ifade etmiştir. Bu çerçevede, komisyonun iki defa toplanabildiğini ve ilk toplantıdan sonra ikinci toplantının uzun süre gerçekleştirilemediğini yazmıştır. İkinci toplantıda ise Okul Müdürü Abdurrezzak Efendi'nin yöneltilen sorulara cevap vermediğini bunu da soruşturmayı sürüncemede bırakma niyetiyle yaptığını belirtmiş̧ir. Bu nedenle de üçüncü bir toplantıya gerek kalmadığını ifade edip, ilk toplantıda müsvedde olarak yazılan ifadeler ile arama sırasında öğrenciler üzerinde bulunan tabaka (tütün tabakası), bıçaklar ve soruşturmada mevzubahis olan saatin kumandanlığa teslimini arz etmiştir (31 Aralık 1894) ${ }^{15}$. Ali Rıza Bey’in arzı Kütahya Redif Liva Kumandanı tarafından Hüdavendigâr Maârif Müdürlüğüne yazılmıştır (1 Ocak 1895). Ali

\footnotetext{
${ }^{14}$ Abdurrezzak Efendi'nin ifadesinden, Soruşturma komisyonunun ilk toplantısını 4 ay önce, yani Mayıs 1894'te yaptı̆̆ 1 anlaşılmaktadır.

${ }_{15}$ Aynı dosyada, (Kütahya Redif Miralayı Ali Rıza Bey’in Kütahya Redif Kumandanlığına hitaben yazmış olduğu, 31 Aralık 1894/19 Kanûn-1 Evvel 1310 tarihli yazı.)
}

\section{History Studies}


Rıza Bey tarafından teslim edilen iki bıçak, bir saat ve tütün tabakası da posta yoluyla Müdürlüğe gönderilmiştir ${ }^{16}$.

Soruşturma süreci devam ederken Kütahya Sancağı İdare Meclisi 9 Ocak 1895 tarihli toplantısında konuyu gündemine almış ve hazırlamış olduğu mazbatayı Hüdavendigâr Vilayeti Maârif Müdürlügüne göndermiştir. Toplantıda, okulda yaşanan probleme ve bu problemin halk nezdindeki etkisine değinildikten sonra soruşturma süreci ve kararlarla ilgili görüşler ele alınmıştır. Bu çerçevede Okul Müdürü Abdurrezzak Efendi'nin görevden alınması teklifinin herhangi bir kanuni dayanağa sahip olmadığ komisyonunun belirlenmesi istenmektedir. Toplantıda Ali Rıza Bey başkanlığında oluşturulmuş komisyona ve bu komisyonun soruşturmayı tamamlayamamasına da atıf yapılmıştır. Diğer taraftan Müdür hakkında şikâyetçi olan muallimlerden Yahya Efendi'nin okuldan uzaklaştırılmasıyla bir miktar suhuletin sağlandığı ancak problemin tamamen bitmediği ifade edilmiştir. Mecliste okul muallimlerinin özel ders vermelerine atıfta bulunularak onların okula atanacak yeni Müdür hakkında da benzer davranışlar sergileyebileceği ifade edilmiştir. Sonuç olarak okuldaki aksaklıkların giderilebilmesi için okula sonradan tayin edilen Ömer ve Mehmed Efendiler ile bevvaplar dışında tüm öğretmenlerin ve Müdürün okuldan gönderilmesi teklif edilmiştir ${ }^{17}$.

Hüdavendigâr Vilayeti Maârif Müdürlüğ̈̈, Ali Rıza Bey tarafindan gönderilen soruşturma dosyasını ve Kütahya Sancağı İdare Meclisi tarafından gönderilen mazbatayı dikkate olarak konu hakkındaki kararını 21 Ocak 1895 tarihinde Maârif Nezaretine arz etmiştir. Maârif Müdürlüğü, yazısında öncelikle soruşturma sürecinden ve soruşturmanın tamamlanamamasından bahsetmiştir. Soruşturmanın tamamlanamaması, işe ehemmiyet verilmemesine ve Okul Müdürü Abdurrezzak Efendi'nin komisyon tarafından yöneltilen sorulara, herhangi bir geçerli neden beyan etmeden, cevap vermemesine bağlanmıştır. Çocukların okul içerisinde birbirlerini bıçakla yaraladıklarının, o öğrencilerin, kanunlar çerçevesinde cezalandırılmayıp kanunlara aykırı olarak dövüldüğünün, mevzuata aykırı olarak okula öğrenci kaydedildiğinin, sınavlarda birinci olan öğrenciye kitap, ikinci olana, mutasarrıfin oğlu olduğu için saat vermek gibi münasebetsizlikte bulunulduğunun, Müdür'ün kendi ifadelerinden anlaşıldığ 1 beyan edilmektedir. Bunun yanında soruşturmada, Okul Müdürü'nün, hakkındaki şikâyetlerin bir kısmına cevap vermemesi, iddiaların doğru olduğuna delil sayılmıştır. Arzda, okulda vukua gelen olayların Okul Müdürü’nün görevinden alınmasını gerektirecek sebepler olmadığı da ifade edilmiştir. Ancak okuldaki disiplinsizliğin ve Müdür ile öğretmenler arasındaki ihtilafın, okulun sağlıklı bir şekilde idare edilmesine engel olacağı, eğitim-öğretim faaliyetlerinin aksayacağı gerekçe gösterilerek, okula sonradan muallim olarak tayin edilmiş olan, Farsça, hesap, hendese, inşa ve kitabet Muallimi Ömer Efendi ile rik'a Muallimi Mehmed Efendi haricinde, Okul Müdürü ve muallimlerin tamamının okuldan çıkarılması teklif edilmiştir. Arzda Okul Müdürlüğüne atanması için Bursa Mekteb-i İdâdîsi müdür muavinlerinden, Kengırı Mektebi İdâdîsi eski Müdürü Abdullah Efendi teklif edilmiştir ${ }^{18}$.

Hüdavendigâr Vilayeti Maârif Müdürlügünün yukarıdaki arzından hemen sonra Bursa Mekteb-i İdâdî Müdür Muavini Abdullah Efendi, Mekteb-i Sultânîden mezuniyetine ve Kengırı (Çankırı) Mekteb-i İdâdî Müdürlügüne atıf yaparak, münhal bulunduğu bilinen Kütahya

\footnotetext{
16 Aynı dosyada, (Kütahya Redif Liva Kumandanlı̆̆ı tarafından Hüdavendigâr Vilayeti Maârif Müdürlüğüne gönderilen 1 Ocak 1895/20 Kanûn-1 Evvel 1310 tarihli yazı.)

${ }_{17}$ Aynı dosyada, (Kütahya Sancağ1 Meclis-i İdaresinin 9 Ocak 1895/28 Kanûn-1 Evvel 1310 tarihli mazbata sureti.). Dosyada vilayete gönderilen mazbatanın aslı da bulunmaktadır.

${ }^{18}$ Aynı dosyada, (Hüdavendigâr Vilayeti Maârif Müdürlügünden Maârif Nezâretine gönderilen, 21 Ocak 1895/9 Kanûn-1 sânî 1310 tarihli arz.)
} 
Mekteb-i İdâdî Müdürlüğüne atanmasını Maârif Nezâretine gönderdiği dilekçe ile arz etmiştir $^{19}$. Kütahya İdâdîsi Müdürlüğüne atanmak isteyen yalnızca Abdullah Efendi değildir. Yaklaşık iki yıl Erzurum İdâdîsi muavin-i evvelliği yapmış olup dört aydan beri açıkta bulunduğunu ifade eden Ahmed Efendi de Maârif Nezâretine göndermiş olduğu dilekçe ile Kütahya İdâdîsi Müdürlüğüne talip olmuştur $(2 \text { Şubat } 1895)^{20}$.

1895/1896 (H. 1313) tarihli Hüdavendigâr Vilayet Salnâmesi'ndeki kayda göre Kütahya İdâdîsi Okul Müdürü Abdullah Feyzi Efendi'dir. Abdullah Efendi müdürlüğün yanında, Fransizca, malumat-1 fenniye dersi muallimidir. Hüsn-i hatt dersi Muallimi Mehmed Efendi, hendese, hesap, Farsça, inşa ve kitâbet dersleri muallimi ise Ömer Fevzi Efendi'dir. Ulûm-1 diniye muallimliği ile Arapça, Türkçe, resim, tarih, coğrafya, usûl-i defteri muallimliği münhal bulunmaktadır ${ }^{21}$. Anlaşılacağı üzere Hüdavendigâr Maârif Müdürlüğünün teklifi ve Abdullah Efendi'nin dilekçesi dikkate alınmış ve Abdullah Efendi okul müdürlüğüne atanmıştır. Yine yukarıda isimleri zikredilen iki muallimin dışındakiler de okuldaki görevlerinden alınmışlardır. Görevine son verilenlerin yerlerine yenileri hemen tayin edilmeyince de bazı derslerin muallimlikleri münhal kalmıştır. Ancak daha sonra münhal muallimlik kadroları asaleten ve vekâleten yapılan atamalarla doldurulmuştur ${ }^{22}$.

\section{Sonuç ve Değerlendirme}

Yukarıda detayları ile aktarılan vakadan anlaşılacağı üzere Kütahya İdâdîsinde görev yapan öğretmenlerin, Okul Müdürü hakkında, Maârif Nezâretine göndermiş oldukları şikâyet dilekçesi ile soruşturma süreci başlamıştır. Burada dikkati çeken ilk nokta Okul Müdürü hakkındaki şikâyet dilekçesinin Hüdavendigâr Maârif Müdürlüğü yerine doğrudan Maârif Nezâretine gönderilmiş olmasıdır. Vilayetlerde, maârif alanında gerçekleştirilecek reformları planlamak, koordine etmek, denetlemek üzere, vilayet maârif meclislerinin kurulması 1869'da yürürlüğe giren Maârif-i Umûmiye Nizâmnâmesi ile kararlaştırılmıştır. İfade edilen meclisler vilayet maârif müdürlüklerinin öncüsüdür. Tanzimat Dönemi’nde bazı vilayetlerde maârif meclisleri açılmışsa da onlar Nizâmnâme'de planlanandan farklı bir hüviyette olmuştur. Maârif müdürlüklerinin temelini oluşturan maârif meclisleri 1881'de çıkarılan irade ile Sultan II. Abdülhamid Dönemi'nde açılmaya başlanmıştır ${ }^{23} .1893$ y1lında bir liva merkezindeki idâdî öğretmenlerinin, şikâyet dilekçelerini vilayet maârif müdürlüğü yerine doğrudan Maârif Nezâretine göndermeleri kurumsallaşmanın tam anlamıyla sağlanamamış olduğunun bir göstergesidir.

Maârif Nezâreti, şikâyet dilekçesini dikkate alarak konuyla ilgili soruşturmanın yürütülmesi için Hüdavendigâr Maârif Müdürü'nü görevlendirmiştir. Hüdavendigâr Maârif Müdürlüguü doğrudan bir soruşturma komisyonu belirlememiştir. Hüdavendigâr Valiliği askeriyeden ve mülkiyeden seçilecek kişilerle bir komisyonun belirlenerek soruşturmanın yürütülmesi ve sonucunun Valiliğe bildirilmesi için Kütahya Mutasarrıflığını görevlendirmiştir. Kütahya

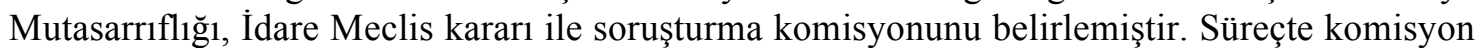
üyeliklerinde değişme olmakla birlikte, komisyonun başkanlığına askeriyeden Albay Ali Rıza Bey atanmıştır. Diğer üyeler İdare Meclisi üyelerinden ve Meclisin kâtibinden oluşmaktadır.

\footnotetext{
${ }^{19}$ Aynı dosyada, (Bursa İdâdîsi muavinlerinden Abdullah Efendi tarafindan Maârif Nezâretine gönderilen, 24 Ocak 1895/12 Kanûn-1 sânî 1310 tarihli dilekçe)

${ }^{20}$ Aynı dosyada, (Erzurum İdâdîsi eski muavin-i evveli Ahmed Efendi tarafindan Maârif Nezâretine gönderilen, 2 Şubat 1895/21 Kanûn-1 sânî 1310 tarihli dilekçe.)

${ }^{21}$ Hüdavendigâr Vilayeti Salnâmesi, 22. defa, Bursa, 1313, s. 298.

${ }^{22}$ Hüdavendigâr Vilayeti Salnâmesi, 23. defa, Bursa, 1314, s. 228.

${ }^{23}$ Vilayet maârif meclisleri ve müdürlükleri hakkında bakınız; Selçuk Akşin Somel, a.g.e., ss. 110-144; Meryem Karabekmez, The Role of Provincial Directors od Education in The Formation of Modern Ottoman Schooling, 18811908, İstanbul Şehir Üniversitesi, Sosyal Bilimler Enstitüsü, yayınlanmamış yüksek lisans tezi, İstanbul, 2012.
} 
Sonradan yapılan değişiklikle Evkaf Müdürü'nün komisyon üyesi olarak görevlendirildiği anlaşılmaktadır. Anlaşılacağı üzere soruşturma komisyonu Valiliğin emri doğrultusunda askeriyede ve mülkiyede görev yapanlar arasından seçilmiştir. Hüdavendigâr Maârif Müdürlüğü, soruşturma komisyonunun belirlenmesini Valilik aracılığı ile Mutasarrıflıktan istemiştir. Bunun temel sebebi sancaktaki eğitim kurumlarının üzerinde maârifi temsil edecek idari bir yapının bulunmayışıdır. Gerçi vilayet maârif meclislerinin ve müdürlüklerinin kurulmaya başlaması ile birlikte sancak ve kazalarda da maârif komisyonları/encümenleri oluşturulmaya başlanmıştır ${ }^{24}$. 1894 tarihinde Kütahya sancağında da bir maârif komisyonu bulunmaktadır ${ }^{25}$. Öyle anlaşıllyor ki o tarihte, sancaklarda oluşturulan maârif komisyonları idari bir anlam ifade etmekten uzaktır. Ancak diğer taraftan soruşturma komisyonu üyesi olarak belirlenen İdare Meclisi Baş Kâtibi Rıfat Efendi aynı zamanda Kütahya Maârif Komisyonu üyesidir. Yine sonradan soruşturma komisyonuna dâhil edilen Evkaf Müdürü İsmail Hakk1 Efendi de Kütahya Maârif Komisyonu üyesidir.

Ele alınan vakada dikkat çekici bir diğer unsur soruşturma takvimidir. Soruşturma süreci 18 Ağustos 1893 tarihinde okul öğretmenleri tarafından Maârif Nezâretine yazılan şikâyet dilekçesi ile başlamıştır. Maârif Nezâretinin soruşturmanın yapılması için Hüdavendigâr Maârif Müdürü'nü görevlendirme tarihi 30 Eylül 1893'tür. Şikâyet dilekçesinin yazımı ile Nezâretin görevlendirme tarihleri arasında 42 günlük bir süre geçmiştir. Şikâyet dilekçesinin Nezârete ulaşması, değerlendirilmesi ve görevlendirme yapılması için geçen, yaklaşık bir buçuk aylık süre makuldür. Hüdavendigâr Valiliğinin, soruşturmanın yapılması için Kütahya Mutasarrıflığına gönderdiği şukkanın tarihi 19 Aralık 1893'tür. Vilayet merkezinde işlemler için geçen süre iki buçuk aydan daha fazladır. Maârif Müdürlüğü ve Valiliğin Nezâretten çok daha yavaş hareket ettiği aşikârdır. Konunun Kütahya İdare Meclisinde ele alındığı tarih 12 Mart 1894'tür. Anlaşılıyor ki yaklaşık iki buçuk aylık bir süre de Kütahya Mutasarrıflığında geçmiştir. Şikâyet dilekçesinin yazılmasından bir soruşturma komisyonunun kurulmasına kadar geçen süre yaklaşık yedi ay olmuştur. Soruşturma komisyonu ilk toplantısını Mayıs 1894'te gerçekleştirerek önce muallimlerin şikâyetlerini dinlemiş ve şikâyetler doğrultusunda Okul Müdürü'ne sorular yöneltmiştir. Aynı gün içerisinde okulda öğrenciler de aranmıştır. O günkü toplantıda Okul Müdürü'nün ifadesi tamamlanamamıştır. Komisyonun ikinci toplantısı 27 Eylül 1894 'te gerçekleştirilmiş ve Okul Müdürü'nün ifadesinin alınmasına devam edilmiştir. İkinci toplantıda Okul Müdürü'nün önceki ifadelerini kabul etmeyeceğini ve kendisine yöneltilen sorulara da sözlü olarak cevap veremeyecek olup daha sonra yazılı olarak cevap vereceğini beyan etmesiyle sonlandırılmıştır. Okul Müdürü'nden yazılı bir cevap da alınamayınca soruşturma komisyonu başkanı Ali Rıza Bey kararını Kütahya Redif Kumandanlığ1 aracılığ 1 ile 1 Ocak 1895 tarihinde Hüdavendigâr Maârif Müdürlüguüne bildirmiştir. Maârif Müdürlüğü de kararını 21 Ocak 1895'te Maârif Nezâretine yazmıştır. Anlaşılacağ 1 üzere Kütahya İdâdîsi Müdürü hakkındaki soruşturma yaklaşık bir buçuk yıl sürmüştür. Bu süreçte okulda eğitim-öğretim faaliyetleri de devam etmiştir. Elbette ki oldukça uzun bir süreyi kapsayan soruşturma sürecinde, yazışmalarda da belirtildiği üzere, eğitimöğretimde aksamalar olmuştur. Soruşturmanın tamamlanmasından sonra da aksamaların bir süre daha devam ettiği okuldaki münhal öğretmen kadrolarından anlaşılmaktadır.

Soruşturma sonunda Okul Müdürü ve şikâyette bulunan öğretmenlerin okuldan uzaklaştırılmasına karar verilmiştir. Diğer taraftan kararda okulda gerçekleşen usulsüzlüklerin, kanunlara göre, Okul Müdürü'nün görevinden alınmasını gerektirecek sebepler olmadığı ifade edilmektedir. Bunun temel sebebi, 1892'de yürürlüğe girmiş olan Vilayat-ı Şahane İdâdî

\footnotetext{
${ }^{24}$ Somel, a.g.e., s. 137.

${ }^{25}$ Hüdavendigâr Vilayeti Salnâmesi, 21. defa, Bursa, 1312, s. 234.
} 
Mekteplerinin İâre-i Dâhiliyesine Mahsus Talîmât'ta idâdî müdürlerinin görev ve sorumluluklarına ayrıntılı yer verilmiş olması; ancak görev ve sorumluluklarını yerine getirmediklerinde ne yapılması gerektiğinin yazılmamış olmasıdır ${ }^{26}$.

Yukarıda aktarılan vakada değerlendirilecek bir diğer konu Kütahya İdâdîsinde yaşanan problemler ve o problemlerin çözüm şekilleridir. Okulda yaşanan problemler aşağıdaki şekilde siralanabilir.

- Öğrenciler arasında bıçakla yaralama vakalarının olması.

- Öğrencilerin sokaklarda halka karşı saygısızlık yapmaları.

- Öğrencilere fiziki şiddet uygulanması.

- Okula usulsüz olarak öğrenci kaydedilmesi.

- Sınavlarda usulsüzlük yapılması. (Sınava girmeyen öğrenciye, girmiş gibi not verilmesi. Sınavlara girmemiş öğrencilerin bir üst sınıfa geçirilmesi.)

- Mükâfat dağıtımlarında usulsüzlük yapılması.

- Okul harcamalarında usulsüzlük yapılması.

- Öğretmenlerin disipline aykırı hareketlerde bulunmaları.

- Öğretmenlerin özel ders vermeleri.

- Maârif Müdürlüğüne bildirilmesi gereken disiplin vakalarının bildirilmemesi.

- Öğrencilere ödül olarak muallimler tarafindan uygun görülen aferin ve tahsin belgelerinin Müdür tarafindan hazırlanıp verilmemesi.

- Derslerine giremeyen muallimlerin yerlerine vekil tayin edilmemesi.

- Öğrencilerin okula bıçak, tütün tabakası getirmeleri.

- Öğrencilerin, muallimlerin karşısında sigara içmeleri.

- Öğrencilerin derslere devamlarının ve okula giriş-çıkış saatlerinin takip edilmemesi.

Yukarıda ifade edilen, Kütahya İdâdîsinde meydana gelmiş problemler, idâdîler için öngörülmüş problemlerdir. Zikredilen problemlerin meydana gelmesi durumunda ne yapılması gerektiğine 1892'de yürürlüğe giren Vilayat-ı Şahane İdâdî Mekteplerinin İdâre-i Dâhiliyesine Mahsus Talîmât'ta yer verilmiştir. Bunlardan bir kaçına aşağıda örnek verilecektir. Talîmâtnâme'ye göre, ders saatlerinde okulda bulunmayan öğrenciler için nişane-i tevbih ve tevkif cezaları öngörülmüştür. Mazeretsiz olarak okulda bulunmama durumunun tekrarında bir üst ceza olan izinsizlik cezası düşünülmüştür. Yine öğrencinin muallimlere hürmetsizlik göstermesi, arkadaşlarını darp etmesi, okuldan kaçması gibi durumlarda tekdir-i aleni cezası tasarlanmıştır. Sonraki tarihlerde Talîmâtnâme'de yapılan değişiklikle yaralayıcı ve zarar verici alet taşıma da ifade edilen cezaya dâhil edilmiştir ${ }^{27}$. Talîmâtnâme'de sonradan yapılan düzenlemelerde yukarıda ifade edilen problemlerin de etkili olduğu anlaşılmaktadır. Öğrenciler arasında yaralama vakaları farklı idâdîlerde de yaşanmıştır. Kengırı İdâdîsinde yaşanan vaka buna örnektir ${ }^{28}$.

Yine, adı geçen Talîmâtnâme'de okula gelemeyecek derecede hasta olan öğretmenin yerine bir vekil öğretmen görevlendirilmesi ifade edilmiştir. Geçerli bir mazereti olmadan derse girmeyen muallimin öncelikle maaşından kesinti yapılması, ayda üç defa derse girmemesi durumunda ise müstafi sayılması gerektiği Talîmâtnâme'de belirtilmektedir ${ }^{29}$. Vakadan anlaşıldığına göre mazeretine binaen veya mazeretsiz olarak derslere girmeyen öğretmenlerin

\footnotetext{
${ }^{26}$ İdâdî müdürlerinin görev ve sorumlulukları için bakınız: Demirel, a.g.t., ss. 63-65.

${ }^{27}$ Demirel, a.g.t., s. 91.

${ }^{28}$ Fatih Demirel, "Osmanlı Modern Eğitim Kurumlarında İşlenen Suçlar", History Studies, 5/1, Ocak 2013, s. 106.

${ }^{29}$ Demirel, a.g.t., s. 79.
} 
yerine vekil tayin etme uygulamasına gidilmemiştir. Bununla beraber, Muallimlerin Müdür hakkındaki şikâyet dilekçelerinden önce derslere girmeyen öğretmen hakkında herhangi bir işlem yapılmamıştır. Mazeretsiz olarak derse girmeme örnekleri farklı idâdîlerde de meydana gelmiştir. Kırkkilise İdâdîsi Türkçe Muallimi Bilal Efendi, derslere girmemiş olması sebebiyle önce maaş kesim cezasına çarptırılmış, bundan sonuç alınamayınca da görevden alınmıştır ${ }^{30}$. İki okulda meydana gelen benzer duruma karşı okul müdürlerinin farklı tutumlar sergilediği anlaşılmaktadır.

1870'e kadar bir disiplin aracı olarak görülen fiziki şiddet, o tarihten sonra modern eğitim kurumlarında ortadan kaldırılmaya çalışılmıştır. Bu, Talîmâtnâmelerde açık bir şekilde ifade edilmiştir. İdâdîler için hazırlanan Talîmâtnâmelerde ise bir disiplin aracı olarak fiziki şiddete hiç yer verilmemiştir. Vakanın bize gösterdiği, kanunlarda yer almamasına, hatta yasaklanmasına rağmen, fiziki şiddetin bir disiplin aracı olarak okul müdürleri tarafindan kullanıldığıdır. Sonraki dönemlerde de farklı eğitim kurumlarında konuyla ilgili örnekler mevcuttur ${ }^{31}$.

\section{Kaynaklar}

\section{Arşiv Vesikaları}

\section{Devlet Arşivleri Başkanlığı Osmanlı Arşivi (BOA)}

Maârif Nezâreti Mektûbî Kâlemi (MF. MKT)

BOA, MF.MKT., 189/86.

BOA, MF.MKT., 251/27.

\section{Salnâmeler}

Hüdavendigâr Vilâyeti Salnâmesi, 21. defa, Bursa, 1312

Hüdavendigâr Vilâyeti Salnâmesi, 22. defa, Bursa, 1313

Hüdavendigâr Vilâyeti Salnâmesi, 23. defa, Bursa, 1314

\section{Telif Eserler}

AYAR, Mesut, "Kırklareli (Kırkkilise) Mekteb-i İdadisi”, History Studies, 2/3, 2010, 39-59.

GÜNDÜZ, Mustafa, “Son Dönem Osmanlı Eğitiminde Disiplin ve Cezalandırma (1847-1920), Doğu Batı, 13/53, 2010, 127-157.

FORTNA, Benjamin C., Mekteb-i Hümayûn (Osmanlı Imparatorluğu'nun Son Döneminde İslâm, Devlet ve Eğitim), Çeviren: Pelin Siral, İstanbul, 2005.

DEMİREL, Fatih, Mekteb-i İdâdî,, Atatürk Üniversitesi, Sosyal Bilimler Enstitüsü, Yayınlanmamış Doktora Tezi, Erzurum, 2010.

, “Osmanlı Eğitim Siteminin Modernleşmesi Sürecinde Hiyerarşi”, Uludağ Üniversitesi Eğitim Fakültesi Dergisi, 25/2, 2012, 507-530.

, "Osmanlı Modern Eğitim Kurumlarında İşlenen Suçlar", History Studies, 5/1, Ocak 2013, 101-112.

\footnotetext{
30 BOA, MF.MKT., 189/86, (16 Ağustos 1893/4 Ağustos 1309). Belge daha önce Mesut Ayar tarafindan kullanılmıştır. Mesut Ayar, "Kırklareli (Kırkkilise) Mekteb-i İdadisi”, History Studies, 2/3, 2010, s. 53.

${ }^{31}$ Demirel, Osmanlı Modern Eğitim Kurumlarında..., s. 108.
} 
KAÇMAZ, Ekrem, Kütahya Lisesi ve Tarihi Gelişsimi, Selçuk Üniversitesi, Eğitim Bilimleri Enstitüsü, Yayınlanmamış Yüksek Lisans Tezi, Konya, 2010.

KARABEKMEZ, Meryem, The Role of Provincial Directors od Education in The Formation of Modern Ottoman Schooling, 1881-1908, İstanbul Şehir Üniversitesi, Sosyal Bilimler Enstitüsü, Yayınlanmamış Yüksek Lisans Tezi, İstanbul, 2012.

KAYA DOĞANAY, Fatma, Tanzimat'tan Cumhuriyet'e Rüşdiye Mektepleri, Atatürk Üniversitesi, Sosyal Bilimler Enstitüsü, Yayınlanmamış Doktora Tezi, Erzurum, 2011.

KÖLEMEN (Yüce), Serap, 19. Yüzyılın Sonu ve 20. Yüzyılın Başlarında Kütahya Sancăgı'nda Eğitim, Afyonkarahisar Kocatepe Üniversitesi, Sosyal Bilimler Enstitüsü, Yayınlanmamış Yüksek Lisans Tezi, Afyon, 2007.

NURDOĞAN, Arzu M., Modernleşme Döneminde Osmanlı'da İlköğretim, İstanbul, 2016.

SOMEL, Selçuk Akşin, Osmanlı'da Eğitimin Modernleşmesi (1839-1908) (İslamlaşma, Otokrasi ve Disiplin), Çeviren: Osman Yener, İstanbul, 2010. 